\title{
Assessment of line differentiation in the Thoroughbred horse breed using DNA microsatellite loci
}

\author{
L.A. Khrabrova $\otimes$, N.V. Blohina, O.I. Suleymanov, G.A. Rozhdestvenskaya, V.F. Pustovoy \\ All-Russian Research Institute for Horse Breeding, Divovo, Ryazan Region, Russia \\ هe-mail:I.khrabrova@yandex.ru
}

\begin{abstract}
The Thoroughbred (TB) horse is the best racehorse breed used in the racing industry. This breed has had a closed studbook for about 300 years. In Russia TB horses have been bred since the second half of the XVIII century. The modern Russian Stud Book register of TB horses is partially presented by stallions and broodmares imported from different countries. The genealogical structure of the breed is represented by 17 lines, among which the Northern Dancer line dominates (30.9\%). The study of features of different lines of TB was carried out on 17 loci of DNA microsatellites (VHL20, HTG4, AHT4, HMS7, HTG6, AHT5, HMS6, ASB23, ASB2, HTG10, HTG7, HMS3, HMS2, ASB17, LEX3, HMS1 and CA425) to assess genetic differentiation of the genealogical structure. The results of the DNA typing of 8091 Thoroughbred horses across microsatellite loci show that the gene pool of the domestic population is represented by 100 alleles typical of the breed. A comparative analysis of the genotypes of horses representing different lines indicates that they differ in the number of alleles (85-99), allele frequencies, the level of polymorphism $A_{e}(2.93-3.48)$ and the degree of the observed heterozygosity $H_{o}(0.653-0.739)$. The genetic distances between the lines varied in a wide range from 0.014 (Nasrullah - Northern Dancer) to 0.125 (Massine - Teddy). The correspondence to HWE was maintained in most lines, which is confirmed by the negative values of $F_{i s}$. Cluster analysis demonstrated the correspondence of the obtained dendrogram of Nei's genetic distances to its genealogical scheme of lines. Genetic differentiation of lines by index $F_{s t}$ varied in a range $0.005-0.073$ at the mean value $F_{s t}=0.024$. The data indicate genetic differentiation of lines of TB at the STR markers and confirm the effectiveness of the system of linear breeding for the maintenance of interbreed biodiversity.
\end{abstract}

Key words: genetic diversity; horse; linear structure; microsatellite DNA; population analysis; Thoroughbred.

For citation: Khrabrova L.A., Blohina N.V., Suleymanov O.I., Rozhdestvenskaya G.A., Pustovoy V.F. Assessment of line differentiation in the Thoroughbred horse breed using DNA microsatellite loci. Vavilovskii Zhurnal Genetiki i Selektsii = Vavilov Journal of Genetics and Breeding. 2019;23(5):569-574. DOI 10.18699/VJ19.526

\section{Оценка дифференциации линий в чистокровной верховой породе лошадей с использованием микросателлитов ДНК}

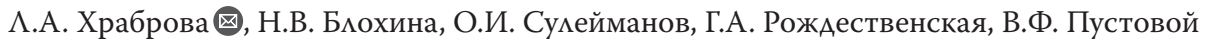

Всероссийский научно-исследовательский институт коневодства, Дивово, Рязанская область, Россия هe-mail: I.khrabrova@yandex.ru

\begin{abstract}
Чистокровная верховая лошадь является лучшей породой для использования в скаковой индустрии. Почти около 300 лет эта порода имеет закрытую племенную книгу. В России чистокровных верховых лошадей разводят со второй половины XVIII в. Современный российский племенной регистр чистокровных верховых лошадей частично представлен жеребцами и племенными кобылами, импортированными из разных стран. Генеалогическая структура породы включает 17 линий, среди которых явно доминирует линия Northern Dancer (30.9\%). С целью оценки генетической дифференциации генеалогической структуры чистокровной верховой породы было проведено изучение особенностей разных линий с использованием 17 локусов микросателлитов ДНК (VHL20, HTG4, AHT4, HMS7, HTG6, AHT5, HMS6, ASB23, ASB2, HTG10, HTG7, HMS3, HMS2, ASB17, LEX3, HMS1 и CA425). Результаты генотипирования 8091 чистокровной верховой лошади по панельным микросателлитным локусам свидетельствуют, что аллелофонд отечественной популяции представлен 100 аллелями, типичными для этой породы. Сравнительный анализ лошадей разных линий показал, что они различаются по числу аллелей (85-99), частотам встречаемости аллелей, уровню полиморфности $A_{e}(2.93-3.48)$ и степени фактической гетерозиготности $H_{o}(0.653-0.739)$. Генетические дистанции между линиями варьировали в широком диапазоне: от 0.014 (Nasrullah - Northern Dancer) до 0.125 (Massine - Teddy). Соответствие распределению HWE наблюдали во всех линиях, что подтверждают отрицательные значения $F_{i s}$. Кластерный анализ продемонстрировал соответствие полученной дендрограммы генетических дистанций по Neі генеалогической схеме линий. Генетическая дифференциация линий по индексу $F_{s t}$ варьировала в интервале 0.005-0.073 при среднем значении $F_{s t}=0.024$.
\end{abstract}




\begin{abstract}
Полученные данные свидетельствуют о генетической дифференциации линий чистокровной верховой породы по STR-маркерам и подтверждают эффективность системы линейного разведения для поддержания внутрипородного биоразнообразия.

Ключевые слова: генетическое разнообразие; лошадь; линейная структура; микросателлит ДНК; популяционный анализ; чистокровная верховая порода.
\end{abstract}

\section{Introduction}

Thoroughbred (TB) is the fastest of the world's most valuable breeds, which is currently bred in 70 countries. The breed was created in England in the XVII-XVIII centuries as a result of crossing imported Arabian and other oriental sires with native mares. The General Stud Book of TB horses was published in 1791 and since that time only the method of purebred breeding has been practiced. Thoroughbred horses were introduced to Russia in the second half of the XVIII century. The first volume of the Russian Thoroughbred Stud Book was issued in 1836 and included 287 stallions and 366 mares. After World War I the TB population was perfected in comparative isolation with a minor exchange of genetic material. At the end of the XX century the country began to import stallions and mares from Europe and the USA for racing and breeding. Currently Russia ranks the fifth in Europe for the number of Thoroughbred mares (Suleymanov, 2016).

The breed has three foundation stallions, Byerley Turk, Darley Arabian and Godolphin Arabian. The most successful sire was Darley Arabian, the line developed through Eclipse and its descendants St. Simon, Irish Birdcatcher and Touchstone. In the mid-twentieth century the lines going back to Phalaris (1913) began to dominate in the breed and this trend has continued to the present time (Vitt, 1957; Konovalova, Klebosolova, 2016).

According to the requirements of the International Stud Book Committee (ISBC) and the International Society for Animal Genetics (ISAG), genetic laboratories must test TB horses using microsatellite loci of DNA as of 2001. The microsatellites are mainly localized in non-coding regions of the genome and are characterized by the codominant type of inheritance and a high polymorphic level. These universal markers are used for parentage verification, in genetic monitoring and population analyses (Wright, Bentzen, 1994; Bowling, Ruvinsky, 2000; Van de Goor et al., 2011; Khrabrova, Blohina, 2018).

Numerous studies indicate a high genetic similarity of TB horse populations in different countries all over the world by STR loci tested (Cunningram et al., 2001; Ling et al., 2011; Blohina, Khrabrova, 2012; Rukavina et al., 2016; Putnova et al., 2018), while Great Britain and the USA keep the leading positions among countries that breed TB horses. In a previous study (Khrabrova, 2009), genetic features of sires of different lines were studied using 13 DNA STR loci.

The aim of our work was to assess the interline differentiation of the modern structure of the Russian population of the breed using 17 microsatellite markers recommended by the ISAG for parentage testing.

\section{Materials and methods}

The object of research was the database of DNA typing of 8091 TB horses registered in the Russian Thoroughbred Stud
Book for the period of 2001-2017, which includes 97-99\% of horses raised in Russia. The reference population included 957 sires and 3194 broodmares and their offspring. Over the period as indicated, 2529 TB horses were imported, most of which (about $65 \%$ ) were used for breeding.

Genomic DNA were prepared from hair follicles or blood samples of TB horses by a standard procedure using Extra Gene $^{\mathrm{TM}}$ DNA Prep 200 and Diatom ${ }^{\mathrm{TM}}$ DNA Prep 200 kits (Laboratory Isogene, Russia) in the Laboratory of Genetics of the All-Russian Research Institute for Horse Breeding, certified by the ISAG based on the Horse Comparison Test (HCT) results.

PCR products of 17 panel microsatellite markers (AHT4, AHT5, ASB2, ASB17, ASB23, CA425, HMS1, HMS2, HMS3, HMS6, HMS7, HTG4, HTG6, HTG7, HTG10, LEX3 and VHL20) were amplified with fluorescently labeled primers (StockMarks ${ }^{\circledR}$, Applied Biosystems) and then analyzed on the automated DNA sequencer ABI 3130. The size of the STR marker was determined using Gene Mapper version 4.0 (Applied Biosystems). Detailed information on microsatellite markers used for parentage control of horses is presented in a work by van de Goor and van Haeringen (2010).

For information on the pedigree and line of horses, the base of the storage-and-retrieval system for managing the selection process in Russian horse breeding "ISS Kony 3" was used (www.ruhorses.ru).

Genetic diversity within the line was evaluated by the basic parameters including total number of allele variants $\left(N_{a}\right)$, effective number of allele $\left(A_{e}\right)$, number of allele per locus $(M N A)$, observed $\left(H_{o}\right)$ and expected heterozygosity $\left(H_{e}\right)$ and Hardy-Weinberg equilibrium (HWE). The coefficients of genetic similarity and genetic distances between the lines were determined by Nei's methods (Nei, 1975) using software Statistica 12 ver.10 (www.StatSoftStatistica.ru). Intrabreed inbreeding and genetic differentiations among lines were estimated by methods of F-Statistics (Weir, 1996) using program FSTAT 1.2 (www2.unil.ch/popgen/fstat.htm).

\section{Results}

The preliminary analysis revealed that at present in the Russian population of Thoroughbred horses the Northern Dancer line dominates, including 2.5 thousand horses (30.9\%). The second place in number is occupied by representatives of the Nasrullah line $(n=1353 ; 16.7 \%)$, the third place, by horses of the young popular line of Mr. Prospector $(n=1040 ; 12.9 \%)$. In general, the genealogical structure of the national population of this breed, as elsewhere in the world, is dominated by the representatives of the lines going back to Phalaris (76.2\%).

The results of DNA typing of 8091 Thoroughbred horses by 17 panel microsatellite loci show that allele's pool of the studied group of horses is represented by 100 alleles. The number of alleles at the loci varied from 4 (HMS1) to 9 (ASB2), 
Table 1. Characteristics of the Thoroughbred lines by the genetic population parameters

\begin{tabular}{|c|c|c|c|c|c|c|c|c|}
\hline Line & $N$ & $N_{a}$ & $A_{e}$ & $H_{0}$ & $H_{e}$ & $F_{i s}$ & $F_{s t}$ & MNA \\
\hline A.P. Indy & 196 & 85 & 3.141 & 0.677 & 0.653 & -0.037 & 0.041 & 5.000 \\
\hline Blandford & 204 & 89 & 3.348 & 0.684 & 0.676 & -0.012 & 0.005 & 5.235 \\
\hline Dark Roland & 138 & 87 & 3.300 & 0.666 & 0.670 & 0.009 & 0.018 & 5.118 \\
\hline Douglas & 380 & 92 & 3.319 & 0.688 & 0.671 & -0.025 & 0.014 & 5.412 \\
\hline Fair Trial & 106 & 85 & 3.198 & 0.672 & 0.660 & -0.023 & 0.029 & 5.000 \\
\hline Hyperion & 49 & 85 & 3.341 & 0.724 & 0.666 & -0.085 & 0.026 & 5.000 \\
\hline Man O'War & 316 & 89 & 3.383 & 0.684 & 0.666 & -0.030 & 0.028 & 5.235 \\
\hline Massine & 105 & 87 & 2.934 & 0.653 & 0.631 & -0.028 & 0.073 & 5.118 \\
\hline Mr. Prospector & 1040 & 95 & 3.390 & 0.674 & 0.671 & -0.004 & 0.018 & 5.588 \\
\hline Nasrullah & 1353 & 97 & 3.355 & 0.680 & 0.673 & -0.011 & 0.013 & 5.706 \\
\hline Native Dancer & 292 & 91 & 3.280 & 0.692 & 0.657 & -0.055 & 0.037 & 5.353 \\
\hline Nearco & 678 & 94 & 3.360 & 0.683 & 0.674 & -0.016 & 0.012 & 5.529 \\
\hline Northern Dancer & 2501 & 99 & 3.423 & 0.680 & 0.678 & -0.003 & 0.006 & 5.824 \\
\hline Prince Rose & 280 & 92 & 3.373 & 0.682 & 0.666 & -0.022 & 0.025 & 5.412 \\
\hline Ribot & 173 & 87 & 3.199 & 0.669 & 0.657 & -0.021 & 0.034 & 5.118 \\
\hline Teddy & 33 & 85 & 3.478 & 0.739 & 0.687 & -0.080 & 0.015 & 5.000 \\
\hline Tourbilon & 129 & 86 & 3.103 & 0.678 & 0.650 & -0.043 & 0.045 & 5.059 \\
\hline Others & 118 & 95 & 3.461 & 0.661 & 0.670 & 0.020 & 0.020 & 5.588 \\
\hline Mean & 8091 & 100 & 3.488 & 0.681 & 0.682 & 0.001 & 0.024 & 5.882 \\
\hline
\end{tabular}

Note: $N$, number of horses; $N_{a}$, number of alleles; $A_{e}$, effective number of alleles; $H_{e}$, expected heterozygosity; $H_{o}$, observed heterozygosity; $F_{i s}$, population inbreeding level; $F_{\text {st, }}$ index differentiation; $M N A$, average number of alleles per locus.

the most of loci show high level of polymorphism. Genetic structure of the Thoroughbred breed is characterized by a high frequency of alleles $A H T 4 O(0.410)$, AHT5K $(0.418)$, ASB17G (0.332), ASB23J (0.323), HMS1J (0.445), HMS2L (0.686), HMS3I (0.571), HMS6P (0.560), HTG4K (0.512), HTG6J (0.482), HTG10I (0.367) and VHL2OM (0.300). The number of alleles on average amounted to 5.88 per locus, the $A_{e}$ level ranged from 1.71 (HMS2) to 5.70 ( $A S B 2$ ) (mean 3.49). The observed heterozygosity $\left(H_{o}\right)$ was 0.681 and varied from 0.418 (HMS2) to 0.854 (ASB2).

Comparative analysis of representatives of different lines on the basis of genetic and population parameters shows (Table 1) that they differ in number of alleles $\left(N_{a}\right)$, level of polymorphism $\left(A_{e}\right)$ and degree of observed heterozygosity $\left(H_{o}\right)$. In the main lines the number of alleles varied in the range of 85-99; polymorphism level $\left(A_{e}\right), 2.934-3.478$; the degree of observed heterozygosity $\left(H_{o}\right), 0.653-0.739$. The leading line of Northern Dancer is characterized by the maximum spectrum of alleles $(n=99)$, sufficiently high levels of polymorphism $\left(A_{e}=3.423\right)$ and the degree of heterozygosity $\left(H_{o}=0.680\right)$.

Horses from small lines of Blandford, Hyperion and Teddy also show high levels of genetic diversity. The domestic Douglas line showed an average level of genetic parameters, but significantly differed in the high frequency of alleles VHL20I, AHT5J, ASB2K, HMS3O and CA425I ( $p>0.999)$.

Horses of the Tourbilon line (1928) going back to Herod (1758) are characterized by a low level of genetic parameters, but stand out from the general background by significantly higher frequencies of alleles VHL20M, AHT4H, HMS7L and $\operatorname{HMS1M}(p>0.999)$.

Another genealogical TB branch going from Matchem (1748) to Man O’War (1917) was represented by 316 horses in our study. Representatives of this line differed markedly from other lines by a high concentration of alleles VHL20L, HTG4M, AHT4H, HTG6G, AHT5J, ASB2B, HTG10O, $H M S 3 P, H M S 2 L, A S B 17 R$ and $C A 425 N$. Significant differences in the frequency of occurrence of individual alleles of 17 STR loci were noted for all analyzed lines, while only the leading abundant Northern Dancer line had an allele frequency structure similar to the population one.

For 16 lines studied, the observed heterozygosity $H_{o}$ exceeded $H_{e}$ and a negative $F_{i s}$ value was recorded, indicating an excess of heterozygous genotypes. Only in the Dark Roland line and a group of others lines the Hardy-Weinberg equilibrium was disturbed $\left(F_{i s}=0.009-0.020\right)$.

Analysis of genetic differentiation of TB lines based on F-statistics showed that index $F_{s t}$ varied in the range of 0.005 0.073 and averaged 0.024 . Within the population index $F_{s t}$ indicates the level of genetic differentiation among subpopulations (in this case among the different lines) and always has positive values ranging from 0 to 1 . The small Massine line had the highest index of fixation $\left(F_{s t}=0.073\right)$. Relatively low values of the differentiation index $\left(F_{s t}=0.005-0.006\right)$ were determined in the lines of Blandford and Northern Dancer.

Estimation of the genetic distances between the breeds, lines and families is important to optimize breeding strategies and 
Table 2. Genetic similarity coefficients (above diagonal) and Nei's genetic distances (below diagonal) between the lines of TB horses

\begin{tabular}{|c|c|c|c|c|c|c|c|c|c|c|}
\hline Line & Mr. Prospector & Native Dancer & A.P. Indy & Nasrullah & Douglas & Tourbilon & Prince Rose & Northern Dancer & Nearco & Fair Trial \\
\hline Mr. Prospector & $x$ & 0.966 & 0.970 & 0.978 & 0.951 & 0.932 & 0.950 & 0.984 & 0.972 & 0.931 \\
\hline Native Dancer & 0.034 & $\mathrm{x}$ & 0.943 & 0.970 & 0.936 & 0.926 & 0.953 & 0.976 & 0.951 & 0.925 \\
\hline A.P. Indy & 0.031 & 0.059 & $x$ & 0.960 & 0.925 & 0.930 & 0.938 & 0.964 & 0.950 & 0.906 \\
\hline Nasrullah & 0.022 & 0.030 & 0.041 & $\mathrm{x}$ & 0.950 & 0.943 & 0.971 & 0.986 & 0.968 & 0.949 \\
\hline Douglas & 0.051 & 0.066 & 0.078 & 0.051 & $x$ & 0.948 & 0.943 & 0.950 & 0.941 & 0.932 \\
\hline Tourbilon & 0.070 & 0.077 & 0.072 & 0.059 & 0.053 & $\mathrm{x}$ & 0.933 & 0.942 & 0.930 & 0.924 \\
\hline Prince Rose & 0.051 & 0.048 & 0.064 & 0.030 & 0.059 & 0.070 & $\mathrm{x}$ & 0.967 & 0.961 & 0.948 \\
\hline Northern Dancer & 0.016 & 0.024 & 0.037 & 0.014 & 0.051 & 0.059 & 0.034 & $x$ & 0.975 & 0.933 \\
\hline Nearco & 0.028 & 0.050 & 0.051 & 0.033 & 0.060 & 0.072 & 0.040 & 0.025 & $x$ & 0.943 \\
\hline Fair Trial & 0.072 & 0.078 & 0.098 & 0.053 & 0.071 & 0.079 & 0.053 & 0.069 & 0.058 & $\mathrm{x}$ \\
\hline
\end{tabular}

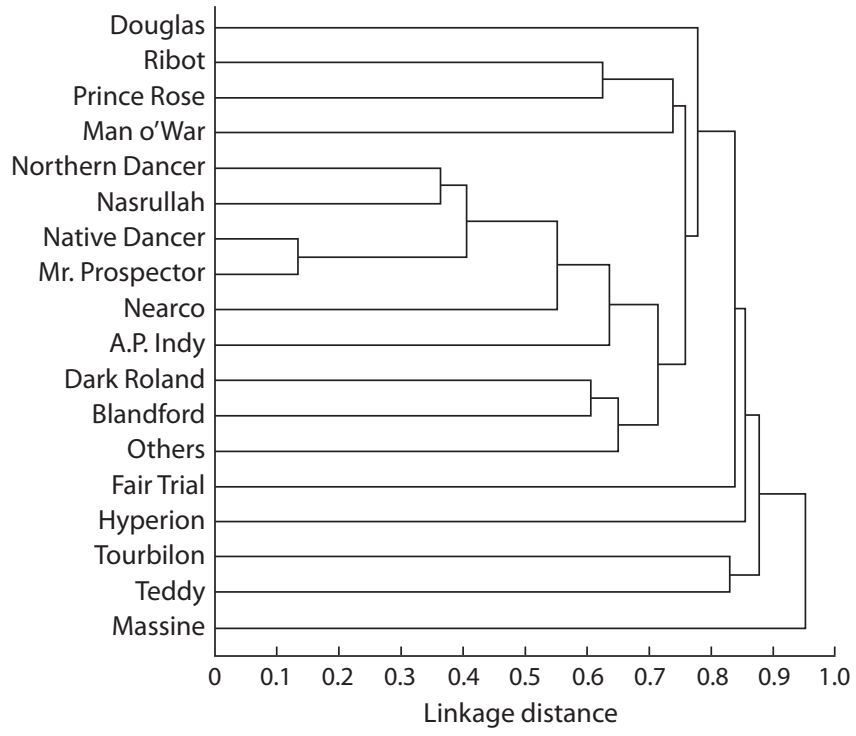

The dendrogram of distances between different lines of Thoroughbred horses by 17 STR loci.

long-term decisions. High coefficients of genetic similarity (Table 2) related lines of Mr. Prospector and Northern Dancer (0.984), as well as Mr. Prospector and Nasrullah (0.978), Mr. Prospector and Nearco (0.972). A minimum genetic similarity was of the lines of Massine and Teddy (0.875), continuing the male line of the ancestors of the Darley Arabian breed.

The genetic distances between the lines varied in a wide range from 0.014 (Nasrullah-Northern Dancer) to 0.125 (Massine-Teddy). The data obtained once more confirm the existence of genetic differentiation of the linear structure in the Thoroughbred horse breed, marking three centuries of purebred breeding.

The genetic differences revealed between the lines in the Russian population of TB horses by STR loci are graphically illustrated on the dendrogram of linkage distances (Figure) built by the method of unweighted pair-group average Euclidean distances that largely coincide with the genealogical scheme of this breed. In the center of the dendrogram is clearly visible a cluster, combining all the base branches of the old line of Phalaris (1913) - Northern Dancer (1931), Nasrullah (1940), Native Dancer (1950), Mr. Prospector (1970), Nearco (1935) and A.P. Indy (1989) lines. A certain genetic relationship can be seen between the lines of Douglas, Ribot and Prince Rose going back to famous stallion St. Simon.

A comparative evaluation of the genetic diversity of microsatellite loci in horses of different lines by the number of alleles, genotypes, polymorphism level and degree of heterozygosity, as well as the dendrogram of genetic distances show that currently among the TB horses tested the most consolidated are the lines of Douglas and Massine that are continued through a limited number of descendants of these stallions.

The analysis of molecular genetic features of TB lines testifies the existence of a certain genetic differentiation of the genealogical structure of the TB horses registered in Russia on the spectrum and frequencies of alleles of satellite DNA. Breeding the lines and obtaining formation on the structure of stud subpopulations contribute to the formation and consolidation of valuable genetic complexes, which, in its turn, causes interbreed heterosis and the progressive development of breeds.

\section{Discussion}

Analysis of the results of genotyping of 8091 Thoroughbred horses shows that the group studied has a breed-specific spectrum and structure of alleles of the all 17 microsatellite loci located on 13 different chromosomes. Only minor differences from TB populations of foreign countries in the frequency of rare alleles were revealed (Jungwoo et al., 2014; Shelyov et al., 2014; Rukavina et al., 2016). The results of a comparative analysis of the genetic structure of different breeds show that the TB breed has its own pool of alleles that remains stable for generations (Khrabrova, 2008; Kalashnikov et al., 2011; Khrabrova, Blohina, 2018).

The formation of the genealogical structure of TB horses in Russia is influenced by global trends in the racing industry and import of horses from the United States and European countries. In recent decades, the lines of Northern Dancer, Nasrullah and Mr. Prospector have been intensively developed due to the import of sires, but the domestic line of Douglas is still important. Of course, the flow of genes has added to the gene pool of the national population, but its influence 
on the genetic structure of microsatellite loci is insignificant (Khrabrova, Blohina, 2018).

The evaluation of the genetic differentiation of the linear structure of TB revealed the presence of genetic characteristics of horses of different lines on the analyzed parameters $\left(N_{a}\right.$, $\left.A_{e}, H_{o}, M N A, F_{s t}\right)$ which confirms the existence of interline differences at the molecular genetic level. Genetic distances between the lines varied in a wide range of $0.014-0.125$, but on average they were not so great as the differences between the breeds (Kalashnikov et al., 2011). Earlier data suggest (Khrabrova, 2009) that genetic differences between TB sires of different lines are more contrasting and Nei's genetic distances varied in a wider interval, 0.041-0.234. In the Thoroughbred horse population of Bulgaria $(n=157)$ the genetic differences between the sire lines on STR loci $\left(F_{s t}=0.048-0.302\right)$ were also established (Vlaeva, Lukanova, 2015). In the Arabian breed genetic distances between the lines varied in a range of 0.040-0.200 (Zaitceva et al., 2010). It is obvious that the genetic structure and size of the reference population have a certain influence on the assessment of linear differentiation in horse breeds.

It can be expected that the interline genetic features revealed cause - to an extent - the effect of intrabreed heterosis, and the Thoroughbred horse breed with all its consolidation still has a genetic resource for further improvement. Another mechanism for maintaining this effect is the genetic differences between the best sires and the fathers of the mares.

The dendrogram of genetic distances between the lines made on the basis of allele frequency matrices of the loci studied is quite consistent with the linear structure of TB horses. The genealogical structure of the breed cluster Darley Arabian - Eclipse - Phalaris, which includes 6 related lines and in total $76.2 \%$ of the TB population, is dominating. Within this cluster, a new line of A.P. Indy (1989) genetically is the most isolated $\left(F_{s t}=0.041\right)$. Molecular genetic and pedigree studies (Cunningram et al., 2001) indicate that the genotype of the founder of the breed, sire Darley Arabian, has played a huge role in the genetic structure of TB horses. In the genealogical scheme of the breed the small Massine line stands out for its genetic individuality and is characterized by the maximum frequency of alleles (VHL20N, HMS7N, AHT5J, and $A S B 17 R$ ) and coefficient $F_{s t}(0.073)$. Undoubtedly, work with the most differentiated lines of Massine and Tourbilon is important for maintaining the diversity of the breed.

Linear breeding is the basis for the reproduction of genetic material in horse breeding, pig breeding and poultry farming (Barmintsev, 1972; Ernst, Zinovieva, 2008; Kharitonov et al., 2018). As an alternative to this method, cattle breeders also practice intensive use of the most valuable bulls, without dividing the breed into groups of animals by origin (Kharitonov et al., 2018). Analysis of boars' genotypes using a panel of DNA microsatellites showed that linear differentiation $\left(F_{s t}=0-0.34\right)$ is available in all pig breeds studied (Ernst, Zinovieva, 2008). In general, the use of genetic markers associated with the productive qualities of individuals significantly increases the efficiency of linear breeding (Boev et al., 2012).

According to V.O. Vitt (1957), it is very important to have a picture of genetic differentiation of Thoroughbred lines and trace the results caused by breeding methods. Genetic certification of lines provides important information about the level of differentiation of the genealogical structure of the breed and allows controlling the level of intrabreed diversity. The undeniable advantage of microsatellite markers is the possibility of their use for studying phylogenetic relationships and microevolution of related breeds, subpopulations or lines. The standardized system of parentage testing for horses of different breeds by DNA microsatellites (van de Goor, van Haeringen, 2010) creates a true opportunity to use the results of testing to assess the diversity of populations and provides genetic control of breeding processes in the populations (Cothran, Luis, 2005; Ernst, Zinovieva, 2008).

\section{Conclusion}

There is a continuous process of development of genealogical structure and changes in the domestic population in the Thoroughbred breed that reflects the general trends of development of the breed. The analysis of genetic features of 8091 TB horses registered in Russia and belonging to 17 basic lines shows that there are differences between them both in the spectrum and frequencies of alleles, the level of polymorphism, the degree of heterozygosity and genetic distances. The data obtained confirm that the method of linear breeding is a reliable mechanism for the preservation of interbreed diversity and is quite effective even with a Thoroughbred breeding system. The system of control of a horse's origin by DNA microsatellites makes it possible to assess effectively the diversity of the breed's genealogical structure and control the selection process at the genetic level.

\section{References}

Barmintsev Yu.N. Horse Breeding and Equestrian Sport. Moscow: Kolos Publ., 1972.

Blohina N.V., Khrabrova L.A. Molecular and genetic features of subpopulations of Thoroughbred horses. Konevodstvo i Konny Sport = Horse Farming and Equestrianism. 2012;4:13-15. (in Russian)

Boev M.M., Kakushka Ye.V., Noshchenko A.S. Evaluation of intralinear rearing and crosses of dairy cattle lines with account for inheritance of genetic markers. Vestnik of the Russian Academy of Agricultural Sciences. 2012;4:72-75. (in Russian)

Bowling A.T., Ruvinsky A. The Genetics of the Horse. Wallingford: CABI Publ., 2000.

Cothran E.G., Luis C. Genetic distance as a tool in conservation of rare horse breeds. In: Bodó I., Alderson L., Langlois B. (Eds.) Conservation Genetics of Endangered Horse Breeds. EAAP Publ. No. 116. Slovenia, Bled, 2005;55-72. DOI 10.3920/978-90-8686-546-8.

Cunningram E.P., Doley J.J., Splan R.K., Bradley D.G. Microsatellite diversity, pedigree relatedness and the contributions of founder lineages to thoroughbred horses. Anim. Genet. 2001;32(6):360-364.

Ernst L.K., Zinovieva N.A. Biological Problems of Livestock in XXI Century. Moscow: Russian Academy of Agricultural Sciences, 2008. (in Russian)

Jungwoo E., Jeong-An G., Bong-Hwan C., Kyoung-Tag D., ByungWook C., Heui-Soo K. Genetic profiling of Thoroughbred racehorses by microsatellite marker analysis. Genes Genomics. 2014;36: 119-123.

Kalashnikov V.V., Khrabrova L.A., Zaitcev A.M., Zaitceva M.A., Kalinkova L.V. Polymorphism of microsatellite DNA in horses of stud and local breeds. Selskokhozyaystvennaya Biologiya $=$ Agricultural Biology. 2011;2:41-45. (in Russian)

Kharitonov S.N., Melnikova E.E., Osadchaya O.Yu., Yanchukov I.N., Ermilov A.N., Sermyagin A.A. In the concern to the question about principles of line breeding in Russian dairy cattle sector. Genetika i Razvedenie Zhivotnyh $=$ Genetics and Breeding of Animals. 2018; 2:13-19. DOI 10.31043/2410-2733-2018-2-13-19. (in Russian) 
Khrabrova L.A. Monitoring of the genetic structure of breeds in horse breeding. Russ. Agric. Sci. 2008;34(4):261-263. DOI 10.3103/S106 8367408040150 .

Khrabrova L.A. Genetic differentiation of the linear structure of Thoroughbred horse by DNA microsatellites. In: Proc. Int. Conf. "Advances in Genetics, Breeding and Reproduction of Agricultural Animals”. St. Petersburg, Pushkin, 2009;2:111-114. (in Russian)

Khrabrova L.A., Blohina N.V. Genetic monitoring of the Thoroughbred breed on loci of DNA microsatellite. Genetika i Razvedenie Zhivotnyh $=$ Genetics and Breeding of Animals. 2018;3:11-16. DOI 10.31043/2410-2733-2018-3-11-16. (in Russian)

Konovalova G.K., Khlebosolova A.V. Thoroughbred Horse Breeding in Russia and Abroad. Moscow: Akvarium-Print Publ., 2016. (in Russian)

Ling Y.H., Ma Y.H., Guan W.J., Cheng Y.J., Wang Y.P., Han J.L., Mang L., Zhao Q.J., He X.H., Pu Y.B., Fu B.L. Evaluation of the genetic diversity and population structure of Chinese indigenous horse breeds using 27 microsatellite loci. Anim. Genet. 2011;42(1):56-63.

Nei M. Molecular Evolutionary Genetics. New York: Columbia Univ. Press, 1987.

Putnová L., Štohl R., Vrtková I. Genetic monitoring of horses in the Czech Republic: a large scale study with a focus on the Czech autochthonous breeds. J. Anim. Breed. Genet. 2018;135(1):73-83. DOI 10.1111/jbg. 12313 .

Rukavina D., Hasanbasic D., Ramic J., Zahirovic A., Ajanovic A., Beganovic K., Durnic-Pasic A., Kalamujic B., Pojskic N. Genetic diversity of Thoroughbred horse population from Bosnia and Herzegovina based on 17 microsatellite markers. Japan. J. Veter. Res. 2016;64(3):215-220. DOI 10.14943/jjvr.643.215.
Shelyov A.V., Melnyk O.V., Suprun I.O., Spyrydonov S.V., Melnychuk S.D., Dzitsiuk V.V., Gorka B.M. The comparative analysis of the allele pool of Thoroughbred horses in different countries. Iran. J. Appl. Anim. Sci. 2014;4(3):637-641.

Suleymanov O.I. International standards in Thoroughbred breeding records. Konevodstvo i Konny Sport $=$ Horse Farming and Equestrianism. 2016;4:6-8. (in Russian)

Van de Goor L.H.P., van Haeringen W.A. A proposal for standardization in forensic equine DNA typing: allele nomenclature for equine-specific STR loci. Anim. Genet. 2010;41(2):122-127. DOI 10.1111/j.1365-2052.2009.01975.x.

Van de Goor L.H.P., van Haeringen W.A., Lenstra J.A. Population studies of 17 equine STR for forensic and phylogenetic analysis. Anim. Genet. 2011;42(6):627-633. DOI 10.1111/j.1365-2052.2011. 02194.x.

Vitt V.O. Practice and Theory of Thoroughbred Horse Breeding. Moscow, 1957.

Vlaeva R., Lukanova N. DNA microsatellite analysis of the Thoroughbred horse population in Bolgaria. Genetic relationships between the studied sirelines. Trakia J. Sci. 2015;83-87. DOI 10.15547/tjs.2015. 01.011 .

Weir B.S. Genetic Data Analysis II: Methods for Discrete Population Genetic Data. Sunderland. MA: Sinauer Associates, Inc., 1996.

Wright J.M., Bentzen P. Microsatellites: genetics markers for the future. Rev. Fish. Biol. Fish. 1994;4:384-388.

Zaitceva M.A., Khrabrova L.A., Kalinkova L.V. Intrabreed diversity on 17 loci of microsatellite DNA in Arabian horses of different lines. Konevodstvo i Konny Sport $=$ Horse Farming and Equestrianism. 2010;1:19-21.

ORCID ID

L.A. Khrabrova orcid.org/0000-0003-2590-8472

N.V. Blohina orcid.org/0000-0001-7406-6385

O.I. Suleymanov orcid.org/0000-0002-4501-6642

G.A. Rozhdestvenskaya orcid.org/0000-0002-7371-8422

V.F. Pustovoy orcid.org/0000-0002-1145-2657

Conflict of interest. The authors declare no conflict of interest.

Received February 08, 2019. Revised May 06, 2019. Accepted May 20, 2019. 